\title{
REFLEKSI PANDANGAN NIETZSCHE TERHADAP MORALITAS DAN KEPENTINGAN DIRI
}

\author{
Ferdinand Indrajaya \\ Jurusan Desain Komunikasi Visual, Fakultas Komunikasi dan Multimedia, \\ Bina Nusantara University, Jln. K.H. Syahdan No. 9, Palmerah, Jakarta Barat 11480 \\ ferdinand_indrajaya@yahoo.ca
}

\begin{abstract}
This research is a reflection, a result from author's contemplative process, in reading one of the texts written by one of the western philosopher at the end of modernity, Friedrich Nietzsche. The reading itself, mainly, was initially started from Nietzsche's own writing in a form of excerpts collected in an anthology entitled Self-Interest. This research wishes to show how Nietzsche responds to existing understanding on traditional morality, which to him is no more than a kind of slave morality. Nietzsche, with his own view on morality is basically orbiting to one of his main theses, Will to Power (der Wille zur Macht); other morality related concerns like self and self-interest are also undetachable to this Will to Power. Within the context of traditional morality, thing like self-interest is considered taboo in contrast with altruistic behaviour (self-less behaviour by emphasizing concerns to others). For Nietzsche, this kind of morality is prevailed necessarily because we're discourageous in facing the arrival of nihilism. From Nietzsche's perspective, an immoralist, a person with selfinterest (within the context of traditional morality) is a 'moralist' him/herself. The one who affirms to nihilism, the one who possesses master morality. At the end of this research, the author gives his own response regarding to his reading on Nietzsche and to aim pragmatic value from this research might be impossible. What might be possible is one can aim at achieving different perspectives on morality and self-interest through Nietzsche's perspective.
\end{abstract}

Keywords: will to power, self-interest, slave morality, master morality, nihilism

\begin{abstract}
ABSTRAK
Penelitian ini adalah hasil dari refleksi penulis dari pembacaan teks dari seorang filosof barat pada ujung modernitas, Friedrich Nietzsche. Adapun pengkajian literatur utama dari penelitian ini bertolak dari tulisan Nietzsche sendiri yang berupa excerpt yang dikumpulkan dalam sebuah antologi tulisan berjudul SelfInterest. Tulisan ini ingin menunjukkan bagaimana Nietzsche menanggapi pemahaman yang berlaku pada moralitas tradisional, yang baginya tidak lain adalah moralitas budak. Pandangan Nietzsche sendiri tentang moralitas, mengorbit pada salah satu pilar utama pemikirannya yaitu Kehendak untuk Berkuasa (der Wille zur Macht); aspek lain terkait moralitas seperti pandangannya tentang diri dan kepentingan diri juga melekat padanya. Dalam pandangan moralitas tradisional, kepentingan diri termasuk salah satu hal yang ditabukan dan sikap altruistiklah (tidak memikirkan diri sendiri dan lebih mengutamakan orang lain) yang lebih diutamakan. Bagi Nietzsche, moralitas semacam ini semata-mata dipertahankan karena manusia tidak memiliki keberanian untuk berhadapan dengan kedatangan nihilisme. Bagi Nietzsche, menjadi seorang yang amoral (dalam lingkup moralitas tradisional), yang ber-kepentingan-diri, justru seseorang yang sangat ber'moral' dalam pandangan Nietzsche. Ia adalah seorang yang mengafirmasi nihilisme, seorang yang memiliki moralitas tuan. Pada akhir tulisan, penulis memberikan tanggapan pribadinya, yang merupakan hasil refleksi terhadap pembacaannya terhadap teks Nietzsche. Bila mengharapkan tujuan yang bersifat pragmatis dari tulisan ini, kiranya akan menjadi tidak mungkin. Namun bila hanya untuk sekedar menambah perspektif yang berbeda dari pandangan Nietzsche tentang moralitas dan kepentingan diri, hal ini dapat dicapai.
\end{abstract}

Kata kunci: kehendak untuk berkuasa, kepentingan-diri, moralitas budak, moralitas tuan, nihilisme 


\section{PENDAHULUAN}

Pemikiran dari Friederich Nietzsche sebagai seorang filsuf di ujung modernitas tidak terlepas dari pandangannya tentang nihilisme dan kehendak untuk berkuasa. Kedua hal ini dapat dikatakan bersifat sentral dari Nietzsche. Ibarat sebuah koin, nihilisme dan kehendak untuk berkuasa hadir saling bersandingan. Pada tulisan ini, kehendak untuk berkuasa dibahas sebatas hubungannya dengan tanggapan Nietzsche terhadap moralitas tradisional dan hubungannya dengan kepentingan diri (selfinterest).

Nietzsche memandang moralitas tradisional sebagai moralitas budak, di mana ia dijunjung semata-mata karena manusia tak siap berhadapan dengan kehadiran nihilisme. Sedangkan menjadi seorang yang amoral dalam lingkup moralitas tradisional adalah bermoral dalam pemahaman Nietzsche. Bagaimana kaitan moralitas versi Nietzsche dengan kepentingan diri (self-interest) inilah yang akan coba dipaparkan. Yang ingin coba ditunjukkan adalah bagaimana kepentingan diri tidaklah bertentangan dengan moralitas versi Nietzschean ini; berkepentingan diri sama dengan bermoral.

Secara teknis, tulisan dibagi menjadi tiga bagian. Pertama, pandangan Nietzsche tentang moralitas sebagai kehendak untuk berkuasa; kedua, perihal diri (self) dan hubungannya dengan yang lain (the others). Pada bagian akhir, penulis akan memberikan refleksi singkat menanggapi pandangan Nietzsche tentang moralitas dan kepentingan diri. Mengenai bagian dari pilar pemikiran Nietzsche sendiri, nihilisme dan kehendak untuk berkuasa, nihilisme tidak akan mendapatkan porsi sebagaimana kehendak untuk berkuasa, namun tetap akan disinggung karena semata-mata sulit membicarakan kehendak untuk berkuasa tanpa sama sekali menyinggung nihilisme. Secara sederhana, nihilisme cukup dimengerti sebagai terdevaluasinya nilai-nilai yang dianggap tertinggi oleh modernitas, termasuk di dalamnya adalah agama, sains, dan pastinya nilai moral tradisional yang bagi Nietzsche tak lain hanyalah rekayasa belaka dari manusia dengan mentalitas budak.

\section{HASIL DAN PEMBAHASAN}

\section{Moralitas sebagai Kehendak untuk Berkuasa}

Bagi Nietzsche, dunia adalah kehendak untuk berkuasa dan moralitas yang termasuk bagian dari dunia pun tak luput darinya. Dunia yang dimaksud Nietzsche di sini adalah dunia kehidupan yang dialami sehari-hari, bukan dunia lain di luar dunia keseharian, dunia yang metafisis. Dalam bahasa Kant, adalah dunia fenomena dan dunia Das Ding An Sich (benda pada dirinya sendiri tidak dapat diketahui). Nietzsche menolak pandangan metafisis (kata benda: metafisika, sebuah cabang dari filsafat yang mencari prinsip pertama dari hal-hal) akan realita semacam ini. Kant, dengan metafisikanya, membuat distingsi tentang dunia, yaitu dunia fenomena dan dunia noumena. Dunia fenomena adalah dunia yang tampak sedangkan dunia noumena adalah Das Ding An Sich, yang pada dirinya sendiri tidak diketahui, yang tetap. Benda pada dirinya sendiri tak dapat diketahui namun penampakan benda-benda sebagai sesuatu itulah yang dapat diketahui bagi subyek manusia. Meja pada dirinya sendiri tidak dapat diketahui, namun sesuatu dapat nampak sebagai meja dalam kategori ruang dan waktu tertentu, yang apriori di dalam subyek manusia. Subyek manusia pada Kant, memiliki 'alat' tertentu yang memungkinkan ia mengetahui realita, ia memiliki kemampuan bersintesa. Hasil sintesa antara yang apriori (pengetahuan yang bukan dari pengalaman) dengan yang aposteriori (yang berasal dari pengalaman) inilah yang menjadi pengetahuan bagi subyek manusia.

Implikasi pandangan ini, subyek manusia, dengan kemampuannya dianggap dapat menjelaskan realita secara utuh. Benda pada dirinya yang tidak diketahui (Das Ding An Sich) menjadi tampak (dunia fenomena) dan diketahui disesuaikan dengan kemampuan mengetahui manusia 
(Hardiman, 2007), disesuaikan dengan 'alat' yang ada di dalam subyek manusia dan memungkinkannya menghasilkan pengetahuan yang absolut tentang realita. Bagi sains, sebagai sebuah manifestasi dari suatu pandangan metafisis, Kant jelas berjasa besar karena ia telah menyediakan syarat kemungkinan bagi pengetahuan yang sahih dalam konteks sains. Ilmu pengetahuan ilmiah (sains) mendapatkan pijakan kokohnya pada Kant dalam mempertanggungjawabkan kesahihan hasil pengetahuannya, namun apakah dunia (realita) niscaya dan universal dapat sepenuhnya dijelaskan dengan kategori-kategori yang dibuat oleh subjek manusia, ini merupakan masalah yang berbeda.

Modernitas, sedemikian berpeluhnya mencari 'alat' untuk menjelaskan realita secara utuh. Ia berusaha sedemikian rupa menetapkan, membekukan realita demi adanya suatu pijakan yang aman bagi hidupnya. Modernitas tidak rela membiarkan dirinya berhadapan dengan yang bergerak. Yang tetap adalah tempat di mana nilai-nilai terebah, yang siap dipakai sebagai pegangan, siap menyediakan arahan bagi manusia. Pandangan semacam ini ditinggalkan oleh Nietzsche dan baginya realita selalu dalam keadaan bergerak, kemampuan manusia untuk mengkategorikan realita tidak sekaya realita itu sendiri.

Dunia bagi Nietzsche adalah dunia sebagai kehendak untuk berkuasa; dunia fenomena yang selalu bergerak, selalu menjadi, always becoming (Seigel, 2005). Dunia yang tidak mungkin ditangkap oleh kategori dan konsep pemikiran manusia. Dengan mencoba mengkategorikannya maka manusia juga akan terperangkap oleh konsep yang dibuatnya sendiri dan maka hanya sebatas itulah dunianya. Konsep dan kategori yang dibuat oleh manusia semata-mata karena ia tidak berani menghadapi realita yang terus bergerak tersebut, tidak tahan untuk terus menerus berhadapan dengan kemenjadian yang tak berujung; takut untuk berhadapan dengan nihilisme. Sains sebagai manifestasi dari metafisika, dianggap sebagai 'pengangkangan' realita itu sendiri, bukan lagi menjadi hanya salah satu pegangan, hanya salah satu versi kebenaran, namun dalam modernitas menjadi satu-satunya dalam menjelaskan realitas. Kant pun bukan satu-satunya pemikir yang dituduh Nietzsche 'mengangkangi' realitas dengan metafisikanya, melainkan seluruh pemikir dalam tradisi filsafat Barat (khususnya dalam modernisme) pun tidak luput dari cibirannya.

Dunia bagi Nietzsche adalah kehendak untuk berkuasa, berbeda dan tidak dimaknai dalam kerangka metafisis (seperti pandangan Kant akan adanya dunia Das Ding An Sich). Kehendak untuk berkuasa bukanlah sebuah substansi yang menjadi pijakan metafisis, sebuah dasar yang tetap; kehendak untuk berkuasa adalah sebuah chaos tanpa dasar. Bila mau dikatakan sebagai hakekat dan bersifat dasariah bagi dunia, ia adalah dasar yang dinamis dan terus bergerak; yang tetap adalah chaos itu sendiri. Hal ini dapat dijelaskan dari kata kehendak (will) dan kuasa (power). Kehendak muncul karena adanya perbedaan kuasa. Kuasa (power) bermakna bila ada yang dilampauinya, dalam hal ini adalah dirinya sendiri. Kehendak hadir karena adanya kekuatan atau kuasa untuk memerintah dan yang diperintah, dan pastinya kehendak adalah pasif terhadap kuasa yang memerintah. Sedangkan kehendak untuk berkuasa adalah dinamis, tidak tetap dan cair, lalu bagaimana hal ini dapat konsisten? Bagi Nietzsche, untuk mematuhi dan menerima suatu perintah juga dibutuhkan kekuatan, yaitu memerintah diri untuk mematuhi. Kehendak untuk berkuasa bersifat memerintah dan sekaligus mematuhi terus menerus; tidak berhenti memerintah dan tidak berhenti mematuhi (Sunardi, 1996). Dengan demikian kehendak untuk berkuasa menjadi tetap dalam kondisi yang dinamis dan terus bergerak.

Terkait dengan masalah moralitas, Nietzsche dengan pemikiran kehendak untuk berkuasa-nya tidak ingin menawarkan nilai-nilai moral baru. Ia tidak seperti Kant yang menunjukkan apa yang harus dilakukan secara niscaya dan universal secara moral. Nietzsche malahan menolak sifat universal dan niscaya yang ada dalam moralitas. Sistem moral yang berlaku, setidaknya dalam modernitas, dianggap sebuah kemunduran; sebuah deklanasi nilai-nilai kehidupan (Copleston, 1965). Moralitas tradisional menjadi tempat berlindung bagi orang-orang yang tidak berani mengatakan 'ya' pada dinamika kehidupan, tidak berani menghadapi nihilisme. Nietzsche melihat moralitas sebagai kehendak untuk berkuasa, ada yang secara aktif memerintah dan mematuhi terus menerus secara reaktif, selalu ada 
tuan dan budak. Dalam hal ini moralitas adalah ekspresi dari kehendak untuk berkuasa. Di mata Nietzsche, moralitas mengekspresikan kehendak untuk berkuasa dari kerumunan (herd) yang bermental budak. Mental budak dari moralitas kerumunan ini mendapatkan perlindungan dan diafirmasi, yang terkuat, oleh Kekristenan.

Nietzsche melihat bahwa kehidupan tidak lepas dari seleksi alam, yang lemah dan tak berdaya lambat laun akan hilang dan musnah. Kekristenan di lain pihak menyediakan tempat berlindung dan menjaga stabilitas kelemahan dan ketakberdayaan ini:

"The species requires that the ill-constituted, weak, degenerate, perish: but it was Christianity turned as conserving force; it further enhanced that instinct in the weak, already so powerful, to take care of and preserve themselves and to sustain one another."

(Nietzsche in Rogers, 1997)

Dalam moralitas tradisional, khususnya dalam kekristenan, mengakui bila manusia lemah dan tak berdaya dianggap sebagai sesuatu yang baik, sedangkan menganggap diri kuat dan mementingkan diri sendiri sebagai pijakan dianggap sebagai sesuatu yang buruk. Nietzsche juga menyerang sifat altruistik (sikap mendahulukan yang lain, tidak egois dan rendah hati) yang telah mentradisi dalam sistem moralitas tradisional dan bagaimana sikap ini juga pararel dengan nilai-nilai yang mendapat tempat dalam tradisi Kekristenan. Mementingkan diri sendiri dan bersikap egois adalah buruk dan mendahulukan kepentingan orang lain adalah baik dan bermoral. Nietzsche melihat hal ini, kembali lagi, hanyalah suatu keengganan untuk menghadapi dinamika hidup. Sikap egois yang secara tradisional ditentang atau dianggap buruk dalam sistem moral, oleh Nietzsche dianggap sebagai sikap yang berani menghadapi hidup. Moralitas dengan nilai-nilainya malahan menjadi penghambat bagi perkembangan manusia, manusia terperangkap di dalamnya, padahal norma-normanya dibuat oleh manusia sendiri. Lebih ekstrem lagi Nietzsche berpendapat bahwa ketika manusia berhenti menjadi seorang yang egois, itulah tanda berkurangnya potensi dan bagian yang terbaik dari manusia:

"An altruistic morality, a morality under which egoism languishes-is under all circumstances a bad sign. This applies to individuals, it applies especially to peoples. The best are lacking when egoism begins to be lacking. To choose what is harmful to oneself, to be attracted by "disinterested" motives, almost constitutes the formula for decadence. "Not to seek my own advantage" - that is merely a moral figleaf for a quite different, namely physiological fact: "I no longer know how to find my advantage"...Disgregation of the instincts - Man is finished when he become altruistic - Instead of saying simply "I am no longer worth anything" the moral lie in the mouth of the decadent says: "Nothing is worth anything - life is not worth anything."

(Nietzsche in Rogers, 1997)

Sikap altruistik ini mentradisi karena manusia sudah cukup merasa nyaman dan aman hidup dalam sistem moral yang demikian dan secara tersirat hal ini mengimplikasikan sikap pesimisme terhadap kehidupan. Kekristenan bagi Nietzsche berdosa besar karena mengafirmasi sikap semacam ini semata-mata demi kepentingan (kelenggangan) Kekristenan itu sendiri. Karena manusia menjadi pesimis terhadap kehidupan di dunia ini, ia mencari perlindungan di dunia 'sana' lewat Kekristenan. Moralitas dalam Kekristenan ini bagi Nietzsche adalah moralitas kerumunan, suatu bentuk moralitas budak.

Tentang moralitas, (altruisme, Kekristenan), Nietzsche menyingkap adanya sudut pandang yang berbeda. Bagi Nietzsche, harus dibedakan antara benar-benar beragama dan bermoral dengan sikap menyerah kepada kehidupan dan menyerahkan tanggung jawab kepada institusi-institusi moral yang dibuat oleh manusia sendiri. Altruisme, sebagai ideologi yang dipijak dalam moralitas, ternyata hanyalah kedok lain bagi sikap egoistik yang justru dianggap buruk secara moral. Memuja sikap altruistik, bersikap tidak egois malahan tindakan yang paling egois dan demi keuntungan (keselamatan) diri sendiri. Hal ini menimbulkan kemunafikan dan ini dicermati oleh Nietzsche: 


\begin{abstract}
"The praise of selfless, the self sacrificial, the virtuous - that is, of those who do not apply their whole strength and reason to their own preservation, development, elevation, promotion, and the expansion of their power, but rather live, in relation to themselves, modestly and thoughtlessly, perhaps even with indifference or irony - this praise certainly was not born from the spirit of selflessness. The "neighbor" praises selflessness because it brings him advantages. If the neighbor himself were "selfless" in his thinking, he would repudiate this diminution of strength, this mutilation for his benefit;"
\end{abstract}

(Nietzsche, Rogers, 1997)

Untuk dapat lepas dari skema moralitas kerumunan / budak ini, manusia harus malahan menjadi amoral. Amoral, di sini bukan saja berarti bernilai rendah dan buruk dalam konteks moralitas kerumunan, namun justru pelampauan moralitas kerumunan tersebut dengan menciptakan nilai-nilai bagi dirinya sendiri. Amoral dapat diartikan sebagai moralitas lain selain moralitas kerumunan itu, suatu moralitas tuan (juga salah satu ekspresi dari kehendak untuk berkuasa) di mana memerintah dan mematuhi terjadi dalam diri sendiri dan dengan jujur demi diri sendiri; tidak menutupinya dengan altruisme sebagai kedok egoisme. Seorang yang amoral (dalam pengertian Nietzsche) bukanlah pencanang kewajiban saja namun juga tidak lari dari kewajiban, dalam hal ini ia malahan lebih ber'moral':

"Immoralists", so Nietzsche says, "are not just persons of duty, but do not escape from their duties."

(Nietzsche in Rogers, 1997)

\title{
Perihal Diri
}

Pandangan Nietzsche tentang diri berbeda dengan apa yang diketengahkan oleh zaman di mana ia hidup. Dalam hal moralitas, tegangan antara diri (self) dengan yang lain (others) selalu muncul dan telah menjadi masalah sejak dari awal modernitas. Diri selalu tidak terlepas dengan yang lain, dan konsisten dengan kritik Nietzsche terhadap altruisme, yang lain atau others, dalam hal ini masyarakat, negara, dilihat sebagai hambatan untuk realisasi bagi diri. Belum lagi dalam Kristianitas, Nietzsche melihat perlakuan yang kejam terhadap diri, di mana pertimbangan tentang diri selalu di bawah dogma-dogma, diri tidak berkuasa atas diri sendiri. Sebagaimana dikatakan di awal bahwa dunia adalah kehendak untuk berkuasa, pandangan Nietzsche tentang diri juga tidak lepas dari pengertian ini. Diri dilihat sebagai sesuatu yang aktif, Diri sebagai kehendak untuk berkuasa bukan dilihat sebagai diri yang selalu mengejar kekuasaan untuk mengendalikan yang lain saja, namun juga berkuasa atas diri itu sendiri. Diri yang mampu melampaui diri itu sendiri (Seigel, 2005). Adalah kehendak yang secara terus menerus mengekspresikan dirinya secara transformatif. Berbeda dengan pengertian diri dalam skema self dan others (terutama dalam pemikiran Yunani klasik dan modern), di mana others merupakan batasan bagi diri untuk bertindak dan diri mendapatkan 'perlindungannya' di yang lain, the others.

Karena diri dilihat sebagai sesuatu yang aktif terus menerus dalam transformasi, maka, diri dilihat juga sebagai sesutau yang terus menjadi. Nietzsche melihat individu sebagai suatu entitas yang terus menjadi, namun proses yang dinamis ini kerap kali oleh moralitas tradisional cenderung distabilkan atau ingin dijinakan, ia tidak dibiarkan merambah keliaran untuk menentukan dirinya sendiri. Altruisme dan Kekristenan mencoba meredam kemenjadian, keliaran diri yang naluriah menjadi warga negara yang baik, menjadi garam dan terang dunia, dan sebagainya. Menjadi apa tidak terlepas dari apa yang telah disepakati oleh norma-norma moral yang berlaku yang dianggap rasional, obyektif, dan universal; dan hal ini dianggap sebagai virtue, sebuah kebajikan, menjadi yang utama. Apa yang obyektif dan universal diterima oleh masyarakat dianggap sebagai sesuatu yang berstatus moral tinggi (mencapai virtue), sedangkan individu sebagai komponen dari masyarakat dilihat potensial hanya dan selama berada dalam kerangka moralitas yang berlaku dalam masyarakat itu sendiri. Potensi individu dalam merealisasikan dirinya direduksi ke dalam fungsi-fungsi sosial yang dianggap rasional, individu dengan nalurinya yang dianggap liar sudah seharusnya dijinakkan: 
"Thus what is really praised when virtues are praised is, first, their instrumental nature and, secondly, the instinct in every virtue that refuse to be held in check by the overall advantage for the individual itself - in sum, the unreason in virtue that leads the individual to allow himself to be transformed into a mere function of the whole."

(Nietzsche in Rogers, 1997)

Dari pandangan ini dapat dilihat bahwa manusia tidak akan pernah menjadi manusia (dengan kata lain akan sama saja dengan kerumunan binatang), bila secara individual ia tidak aktif mentransformasi dan mengatasi dirinya lewat kemampuan dan potensinya. Diri yang ideal bagi Nietzsche adalah individu yang radikal mutlak. Tiap individu adalah unik dan tidak mungkin direduksi begitu saja dalam keumuman masyarakat. Individu yang radikal adalah diri yang selalu dapat mengatakan 'ya' pada dinamika kehidupan, berani menciptakan nilai-nilainya sendiri, tidak tunduk begitu saja terhadap dan mencari perlindungan dari norma-norma moral yang ditentukan oleh the others; meskipun hal ini dapat mengakibatkan diri menjadi terasing:

"All our action are altogether incomparably personal, unique, and individual (the Gay Science). Beware of the good and the just. They like to crucify those who invent their own virtue for themselves - they hate the lonely one."

(Nietzsche in Rogers, 1997)

\section{Perihal Kepentingan Diri}

Radikalisasi diri / individu bagi Nietzsche teraplikasikan dalam sikap yang egoistik (selfish). Dari pandangan individu radikal ini dapat diwajari bila egoisme mendapatkan tempatnya yang cukup tinggi dalam pemikiran Nietzsche. Egoisme di sini bukan egoisme yang coba ditekan dan ditutuptutupi oleh altruisme dan Kekristenan, namun egoisme yang jujur apa adanya; pengandaian yang dipakai adalah bahwa setiap orang sebenarnya egois. Sikap egois yang ada dalam diri manusia merupakan ekspresi juga dari kehendak untuk berkuasa, jadi bukan sebaliknya: ego yang menghasilkan kehendak untuk berkuasa.

Memiliki sikap yang egois berarti melihat bahwa diri sebagai sesuatu yang penting. Kepentingan diri dalam hal ini sangat tidak bertentangan dengan sikap seorang egois. Manusia yang egois adalah manusia yang dapat terus menerus mentransformasi dirinya maka dari itu apa yang menjadi kepentingan dirinya untuk tetap dalam keadaan menjadi, tidak bisa dikesampingkan. Orang yang memiliki kepentingan diri dan egois adalah pribadi yang terhormat, yang mau terus maju berhadapan dengan nihilisme. Sedangkan orang yang menganggap bahwa egoisme adalah buruk adalah orang dengan moralitas kawanan atau budak, bukan moralitas tuan. Sulit rasanya menemukan sikap egois yang ekspresif dalam moralitas budak:

"The natural value of egoism. - The value of egoism depends on the physiological value of him who possesses it; it can be very valuable, it can be worthless and contemptible. Every individual may be regarded as representing the ascending or descending line of life. When one has decided which, one has thereby established a canon for the value of his egoism. If he represents the ascending line his value is in fact extraordinary and for the sake of the life collective, which with him takes a step forward, the care expended on his preservation, on the creation of optimum condition for him, may even be extreme. For the individual, the "single man", as people and philosophers have hitherto understood him, is an error: he does not constitute a separate entity, an atom, a "link in the chain", something merely inherited from the past - he constitutes the entire single line "man" up to and including himself....If he represents he descending development, decay, chronic degeneration, sickening (-sickness is, broadly, speaking, already a phenomenon consequent upon decay, not the cause of it), then he can be accorded little value, and elementary fairness demands that he take away as little as possible from the well-constituted. He is no better than a parasite on them..."

(Nietzsche in Rogers, 1997) 
Namun bila sikap egois tidak bertentangan dengan konsep kepentingan diri, lalu apa kepentingan diri bagi Nietzsche? Untuk menjawab pertanyaan ini, perlu diketahui terlebih dahulu apa arti kebahagiaan bagi Nietzsche karena kepentingan diri merupakan apa yang harus dilakukan atau yang harus ada semata-mata supaya manusia dapat mencapai kebahagian. Kebahagiaan, dalam pengertian umum, misalnya merasa bahagia dan puas karena sukses dalam karir, mendapat gaji yang besar, dipuji atasan, dan lain sebagainya, tidak berlaku bagi Nietzsche. Kebahagian bukanlah sematamata dicapai dengan sukses menjalani hidup, tapi juga merayakan kehidupan itu sendiri; meskipun nilai-nilai runtuh namun tetap katakan 'ya' (ja sagen) pada kehidupan, dengan demikian individu selalu optimis dan dalam proses transformasi. Tidak pesimis dan menyerah dengan nihilisme di depan mata. Menghidupi kehidupan senihil apapun kehidupan itu, inilah kebahagian bagi Nietzsche.

Untuk tetap dapat bersikap optimis dalam merayakan kehidupan (dengan segala kebusukannya), seseorang harus memiliki hasrat untuk hidup yang tidak pernah hilang selama egoisme masih dipegang, sebuah libido vitalis, inilah kepentingan diri bagi Nietzsche.

"It is not the works, it is the faith that is decisive here, that determines the order of rank - to take up again an ancient religious formula in a new and more profound sense; some fundamental certainty that a noble soul has about itself, something that can not be sought, nor found, nor perhaps lost."

(Nietzsche in Rogers, 1997)

Nietzsche memiliki keyakinan bahwa kehidupan sepenuhnya bermakna dan lewat hasrat (cinta kehidupan), libido vitalis, manusia mengimani kehidupan itu sendiri. Kata "iman" di sini atau faith bukan dalam konteks keagamaan tertentu, namun jauh lebih mendalam (profound) dari pada itu. Manusia butuh hasrat yang 'liar' dan kuat untuk mengimani bahwa tiap gejolak kehidupan adalah sebuah perayaan tersendiri. Menurut hemat penulis, hal ini menjadi signifikan bila membandingkan pandangan Nietzsche tentang hasrat dengan pandangan dari Plato. Hasrat bagi Nietzsche bukanlah sesuatu yang harus dibendung dan dijinakkan nalar. Konsep Plato tentang kepentingan diri, sebaliknya, malahan hasrat atau nafsu (passion) merupakan subordinasi dari nalar dan harus dijinakkan (Plato in Rogers, 1997). Namun hal ini dapat terjadi dalam skema pemikiran Plato tidak terlepas dari tiadanya pembedaan antara self dan others. Self dan others berhubungan secara organik seperti alam raya, dalam sebuah kosmos dan supaya tetap harmonis, demikianlah nafsu-nafsu yang liar pada diri manusia harus dikendalikan supaya tidak terjadi chaos.

Berbeda dalam modernitas, hubungan antara self dan others selalu berada dalam status yang berlawanan dan bila dalam hubungan seperti ini rasionalitas tetap dipaksakan untuk mengatasi nafsu dan hasrat, yang terjadi adalah rasionalisasi hasrat, sebab biar bagaimanapun kekayaan aspek manusia memang tidak dapat direduksi sebagi mahluk rasional saja, namun juga mahluk yang berkehendak, mahluk yang memiliki hasrat. Nafsu dan hasrat yang sejak jaman Plato selalu berusaha dipendam oleh nalar, mendapatkan dukungannya pada pemikiran Nietzsche (Solomon, 2003). Nalar dan rasionalisasi yang mengejawantah dalam moralitas tak lebih dari sebuah kemunafikan, sebuah egoisme yang disembunyikan dibanding dirayakan. Lalu apakah dengan ini Nietzsche secara tidak langsung ingin mengatakan bahwa kita harus tunduk pada hasrat dan akhirnya diperbudak oleh hasrat? Tidak, bila demikian manusia akan jatuh ke dalam pesimisme total bahwa segala sesuatunya adalah kehendak dan manusia menjadi budak kehendak. Telah disebutkan pada bagian 'Moralitas Sebagai Kehendak Untuk Berkuasa' bahwa seorang yang amoral (dalam pengertian Nietzsche) bukan berarti hanya dapat mencanangkan kewajiban saja, tapi juga tidak lari dari kewajibannya, ia mengatasi kewajibannya. Hubungan dengan hasrat, manusia bukan hanya mahluk berhasrat saja namun ia juga harus mampu mengatasi hasratnya. One needs to be passionate to overcome one's passion. 


\section{SIMPULAN}

Pada bagian simpulan ini, penulis ingin menanggapi dua hal. Yang pertama adalah hubungan moralitas dengan kepentingan diri pada pemikiran Nietzsche dan yang kedua adalah tanggapan terhadap 'individu radikal' dari Nietzsche. Pertama, dari zaman Sokratik, Plato, kita sebut saja sebagai zaman Yunani klasik, Moralitas dan kepentingan diri tidak dapat dipisahkan. Hidup dari seseorang (self) tidak terlepas dari konteks sosialnya (others) dalam kehidupan berbentuk polis. Hidup yang baik adalah termasuk dalam kepentingan diri. Pada zaman modern, hubungan ini berubah. Kepentingan diri adalah sesuatu yang di luar moralitas. Deontologi dari Kant dan berkembangnya utilitarianisme menunjukkan hal ini. Deontologi hanya membicarakan tentang apa yang wajib kulakukan, tanpa mempertanyakan mengapa dan untuk apa; dan utilitarianisme yang lebih mementingkan kepentingan yang lain dibanding diri sendiri sehingga kepentingan diri tidak mendapat tempat di dalamnya. Pemikiran kepentingan diri bagi Nietzsche melampaui dua era ini (Yunani klasik dan modern). Sikap altruistik dalam utilitarianisme (juga didukung oleh Kekristenan) malahan dianggap sebagai penghambat proses transformasi yang dinamis dari individu. Pertimbangan akan yang lain (others) dalam moralitas tidak dipertimbangkan oleh Nietzsche, karena dianggap memperbudak. Dengan ini, kepentingan diri bukan saja di luar moralitas, namun lebih jauh lagi kepentingan diri tidak mungkin ada kalau masih ada moralitas dan Nietzsche memilih untuk menghapus moralitas (dalam arti moralitas kerumunan, herd, yang dilihat sebagai penjara). Kedua, radikalisasi individu dari Nietzsche sangat memungkinkan untuk menghasilkan kehidupan yang sangat sepi menyendiri dan merupakan tantangan yang sangat besar untuk dapat hidup seperti itu dalam kondisi kehidupan zaman sekarang. Walaupun tantangannya sangat berat, namun setidaknya kita dapat belajar tentang identitas diri darinya. Globalisasi dengan teknologi informasinya di era ini semakin deras menghujani kita dengan 'paket-paket' identitas lewat media-media komunikasi, sebuah bentuk perbudakkan baru. Pandangan Nietzsche tentang 'individu radikal' setidaknya dapat membantu kita untuk berani melampaui atau setidaknya merefleksikan apa yang dihempaskan globalisasi kepada kita, dan menentukan nilai-nilai kita sendiri tanpa harus terseret ke kerumunan (herd) global. Tidak mengatakan 'ya' pada kerumunan, tapi 'ya' untuk nilai-nilai yang secara jujur masih kita percayai dengan tidak mengafirmasi begitu saja terhadap dogma dan doktrin tertentu.

\section{DAFTAR PUSTAKA}

Bloomfield, P. (2008). Morality and self-interest, London: Oxford University Press.

Copleston, F. (1965). A history of philosophy vol.7, modern philosophy part 11, Schopenhauer to Nietzsche, London: Image Book Edition.

Copleston, F. (1975). Friedrich Nietzsche, philosopher of culture, London: Harper \& Row Publishers, Inc.

Hardiman, B. (2007). Filsafat modern, dari Machiavelli sampai Nietzsche, Jakarta: Gramedia Pustaka Utama.

Rogers, K. (1997). Self-interest, an anthology of philosophical perspectives, London: Routledge.

Seigel, J. (2005). The idea of the self, thought and experience in Western Europe since the seventeenth century, London: Cambridge University Press.

Solomon, R. (2003). Living with Nietzsche, what the great immoralist has to teach us, London: Oxford University Press, Inc.

Sunardi, St. (1996). Nietzsche, Yogyakarta: LKiS. 